Anna Pikała

Uniwersytet Łódzki

\title{
Autorytet nauczyciela szkolnych przedmiotów artystycznych
}

\author{
Najmniej działa się tym, co się mówi, \\ więcej tym, co się robi, a najwięcej tym, \\ kim się jest (Seneka)
}

Na przestrzeni dziejów pojęcie autorytetu ulegało społecznym i ustrojowym przemianom. Terminu tego zaczęto używać na określenie zarówno prestiżu, powagi, wpływu, znaczenia, jak i woli podporządkowania się władzy ${ }^{1}$. Obecnie dominuje pogląd, że czasy współczesne to okres upadku wielu autorytetów. Instytucje powszechnie dotąd kojarzone z pewnym autorytetem (dom rodzinny, szkoła, Kościół) w opinii młodego pokolenia nierzadko są instytucjami anachronicznymi, które nie mają mu nic ciekawego do zaoferowania. Rodzice coraz częściej przeżywając problemy wychowawcze z dorastającymi dziećmi, nie radzą sobie z konfliktami, uzależnieniami młodych ludzi, liczą na pomoc szkoły, nauczyciela, różnych instytucji. Autorytet utraciła też władza państwowa, instytucje odpowiedzialne za przestrzeganie prawa. Aktualnie to głównie media, tabloidy prezentują wzorce osobowe. Moralizatorstwo uprawiane przez rodziców, szkołę, Kościół napotyka często na bunt, agresję młodzieży. Wspomniane media mają wpływ na kształtowanie wizerunku wymienionych trzech autorytarnych do tej pory instytucji, nagłaśniając przypadki negatywne, natomiast zupełnie pomijając przykłady godne naśladownictwa.

Czy współczesny człowiek potrzebuje autorytetów? Jeśli tak, to jakich? Z pewnością każdy (a młody człowiek szczególnie) potrzebuje w życiu drogowskazu, wzoru, punktu odniesienia, wpływu kogoś lub czegoś, co może być pomocą w sytuacją trudnych wyborów, konfliktów. Uznawanie autorytetów przez młode pokolenie właściwie je kierunkuje, wskazuje nie-

\footnotetext{
${ }^{1}$ M. Szymański, Nauczyciel jako profesjonalista, „Nowa Szkoła” 2005, nr 6.
} 
podważalne wartości, możliwe działania, zapobiega niepożądanym moralnie i społecznie zachowaniom.

Autorytet nauczyciela bardzo często jest łączony z jego kompetencjami, przygotowaniem zawodowym, cechami osobowości. W świadomości społeczeństwa polskiego narasta obecnie przeświadczenie, że szkoła, powszechna edukacja nie wspomagają rozwoju osobowości, zdolności twórczych, zainteresowań, postaw kreatywnych dzieci i młodzieży. Stan ten jest jedną z głównych przyczyn podejmowania częstych prób doskonalenia, modyfikacji systemu oświaty. Towarzyszy temu niejednokrotnie przekonanie, że o efektach, sukcesach szkolnych młodego pokolenia decyduje w pierwszej kolejności nauczyciel, jego postawa, umiejętności i wiedza - kwalifikacje. Czasy współczesne wymagają nowych, bogatszych kompetencji nauczyciela. Zdaniem Wacława Strykowskiego, kompetencje to zdolność do działania, stanowiąca syntezę trzech komponentów: wiedzy, umiejętności i posta$w^{2}$. Takie ujęcie zakłada, że nauczyciel posiada:

- kompetencje merytoryczne,

- kompetencje psychologiczno-pedagogiczne,

- kompetencje komunikacyjne i negocjacyjne,

- kompetencje autoedukacyjne ${ }^{3}$.

W ramach kompetencji merytorycznych nauczyciel ma posiadać dogłębną wiedzę i znajomość materiału z przedmiotu, którego naucza. Kompetencje psychologiczno-pedagogiczne wiążą się z dysponowaniem wiedzą z zakresu psychologii rozwojowej, wychowawczej, a także ze znajomością podstawowych założeń i procedur uczenia się (koncepcja: behawiorystyczna, kognitywistyczna, humanistyczna). Z kolei kompetencje komunikacyjne i negocjacyjne wynikają z faktu, że proces dydaktyczny jest ciągłym procesem komunikacji, dyskusji z uczniami. Natomiast kompetencje autoedukacyjne dotyczą rozwoju zawodowego nauczyciela i samokształcenia. Powyższe podejście jest zgodne z personalistyczną koncepcją modelu edukacji nauczycielskiej, w której podkreśla się wartość wielostronnego rozwoju kompetencji nauczyciela. Jest on tu wzorem osobowościowym na tyle charakterystycznym i interesującym, by z punktu widzenia ucznia być godnym naśladowania ${ }^{4}$.

Do kształtowania zdolności twórczego myślenia i działania, rozwijania otwartej postawy na świat, kreatywności, szczególnie predestynowane są

\footnotetext{
${ }^{2}$ W Strykowski, Kompetencje nauczyciela szkoły współczesnej, „Edukacja Medialna” 2002, nr 4.

${ }^{3}$ Ibidem, s. 5-13.

${ }^{4}$ R. Meighan, Edukacja elastyczna. Jutro twojego dziecka decyduje się dzisiaj, Toruń 1991, s. 57.
} 
przedmioty powszechnej edukacji estetycznej (muzyka, plastyka, wiedza o kulturze), formy aktywności artystycznej podejmowane w ramach działań szkolnych, ale również pozalekcyjnych i pozaszkolnych. Aby zajęcia te odbywały się w sposób efektywny, a zarazem atrakcyjny dla uczniów, potrzebny jest świadomy swej odpowiedzialności, dobrze przygotowany, permanentnie doskonalący się nauczyciel - animator. Nowoczesny system oświaty potrzebuje nauczyciela nowatora i twórcy, o uznanym autorytecie i prawidłowym stosunku do uczniów i środowiska. Potrzeba ta wynika z przeświadczenia, że o przemianach w systemie edukacji decydują przede wszystkim światli, kompetentni i twórczy nauczyciele. Z tego względu działalność nauczyciela musi być ustawicznie korygowana, modelowana, a system wiedzy i umiejętności powinny zmieniać swoją strukturę. Tendencje te można ujać parami: od faktologii do technologii kształcenia; od reprodukcji wiedzy do jej interioryzacji i wielostronnych operacji; od eklektyzmu i fragmentaryczności do pełnej systematyzacji i strukturyzacji ${ }^{5}$. Należy także podkreślić, że współczesny nauczyciel postrzegany jest nie tylko jako społecznie izolowana jednostka, lecz także jako element składowy systemu oświaty, będącego częścią układu społecznego. Dlatego też kompetencje nauczyciela, jego postawa wobec uczniów, rozwój zawodowy, dokształcanie, doskonalenie, w którym uczestniczy, rozpatruje się jako integralną część naprawy całej oświaty. Wspomniane dokształcanie, doskonalenie, samokształcenie służą pogłębianiu, odnawianiu, uzupełnianiu wiedzy i umiejętności, rozwijaniu osobowości. Działania te są niezbędne do podnoszenia sprawności zawodowej, do własnego rozwoju osobowego nauczyciela, do optymalizacji procesu dydaktycznego.

Współczesny nauczyciel nie może być wyłącznie dydaktykiem, preferującym dyrektywno-autorytarny styl pracy z uczniami. Stąd potrzeba uwzględniania w szerszym zakresie w programach kształcenia, dokształcania, doskonalenia - dydaktyk szczegółowych, dyscyplin kierunkowych. Ważne jest też określenie związków mechanizmów rozwoju zawodowego i awansu nauczycieli z ich dokształcaniem, doskonaleniem.

Edukacja kulturalna łączy się często z edukacją estetyczną i artystyczną, traktuje się ją jako przygotowanie do podejmowania kontaktów z szeroko rozumianą sztuką profesjonalną i amatorską (zapoznawanie uczniów z kanonem sztuki w różnych dziedzinach, rozwijanie wrażliwości, zdolności

\footnotetext{
${ }^{5}$ W. Prokopiuk, O nowych realiach funkcjonowania nauczyciela w zawodzie, [w:] idem (red.), Modernizacje systemów edukacyjnych a zawód nauczyciela, Białystok 1990.
} 
percepcyjnych, postaw kreatywnych). Należy mieć na uwadze, że edukacja kulturalna nie jest dodatkiem do programów nauczania. Stanowi alternatywę dla edukacji instrumentalnej, wyposażającej w niezbędne w danym momencie umiejętności. Kompetencje nauczycieli mogą być więc łączone albo głównie ze sprawnościami i tak rozumianą wiedzą profesjonalną, albo z poznawaniem świata, innych osób, siebie, współdziałaniem $\mathrm{z}$ innymi, konstruktywnym przekształcaniem rzeczywistości, dążeniem do wartości wyższych, podmiotowym decydowaniem o własnym życiu. Ta ostatnia opcja wymaga co najmniej równoważnego traktowania wiedzy profesjonalnej i przedmiotowej, także wiedzy normatywnej, ogólnej, dotyczącej danej dziedziny ${ }^{6}$. Tymczasem aktualnie bardzo często główny ciężar kształcenia, dokształcania, doskonalenia nauczycieli spoczywa na kompetencjach metodycznych. Sposoby działania (metody) wzbudzające zainteresowanie i pozytywne nastawienie uczniów do przedmiotów artystycznych zaczynają dominować nad kompetencjami przedmiotowymi. Być może wynika to z faktu, że szkoła ma być miejscem dialogu nauczyciel - uczeń. Ale skoro tak, to nauczyciel muzyki, sztuki, wiedzy o kulturze, oprócz warsztatu metodycznego, ma posiadać wiedzę i to nie tylko z pedagogiki i psychologii, ale i z filozofii (zwłaszcza aksjologii), etyki, estetyki, logiki, historii kultury, antropologii kulturowej, wiedzy o sztuce, o mediach, o współczesnej kulturze, o komunikacji społecznej, a także o sytuacji społeczno-politycznej w kraju i na świecie. Kształcone, doskonalone kompetencje nie zakładają encyklopedycznej wiedzy z różnych dziedzin, ale umiejętność dostrzegania związków różnych zjawisk, ich kontekstu, poznanie możliwie szerokiego zakresu pojęć ogólnych, które warunkują proces myślenia ${ }^{7}$.

Wiek XXI wymaga od nauczyciela profesjonalizmu, skuteczności, fachowości, zaangażowania we własny rozwój. Preferowany jest typ refleksyjnego obserwatora świata, świetnie zorientowanego w swojej dziedzinie, sprawnego dydaktyka, przewodnika po świecie wiedzy, posiadającego umiejętność kształtowania relacji interpersonalnych z uczniami, „przekaźnika i strażnika" wartości niezmiennych.

Rzeczywistość zepchnęła zawód nauczyciela (zwłaszcza nauczyciela muzyki, plastyki, wiedzy o kulturze) w dół rankingów zawodowych. Ogólnie panuje pogląd, że nauczyciel nie lubi nowoczesności, bo trzeba się jej

${ }^{6} \mathrm{~K}$. Olbrycht, Kształcenie nauczycieli do prowadzenia edukacji kulturalnej, [w:] R. Gmoch, A. Krasnodębska (red.), Kompetencje zawodowe nauczycieli i jakość kształcenia w dobie przemian edukacyjnych, Opole 2005, s. 42.

${ }^{7}$ Ibidem. 
nauczyć, trzeba ją studiować i ustawicznie poznawać, a to właśnie on jest od nauczania, a nie bycia nauczanym ${ }^{8}$. Swoistość zawodu nauczyciela sprawia, że trudno określić, na czym polega pełne przygotowanie zawodowe do realizacji zadań dydaktyczno-wychowawczych, animatorskich. Przygotowanie to należy rozumieć całościowo i procesualnie. Całościowo, gdyż pełne przygotowanie obejmuje osobowość, wymaga od nauczyciela nie tylko doskonalenia zawodowego, ale głównie rozwoju prowadzącego ku byciu sobą. Procesualnie, ponieważ rozwój człowieka jest procesem ciągłym, zobowiązującym do nieustannego doskonalenia. W tym kontekście rozwój nauczyciela, w odróżnieniu od rozwoju innych osób, przestaje być tylko czymś prywatnym, gdyż stanowi element przygotowania zawodowego 9 .

Model współczesnej szkoły lansuje też wzór nauczyciela otwartego i dobrego psychologa. Służy on swoją wiedzą i umiejętnościami uczniom, inspiruje ich do pracy twórczej, stymuluje rozwój, zabiega o budowanie atmosfery bezpiecznego funkcjonowania ucznia w klasie i w szkole. Nauczyciel musi umieć uczyć innowacyjnie, sprawować nie tylko funkcję kształcącą, lecz również opiekuńczą, która pozwoli wychowankom szybko i racjonalnie reagować na wszystko, co warunkuje zaspokojenie ich potrzeb. Współczesna szkoła dumna z osiągnięć dydaktycznych i wysokiego poziomu nauczania koncentruje się zdecydowanie właśnie na tych formalnych aspektach, zostawiając na marginesie swoich poczynań obowiązek wychowania, odsuwając na plan dalszy rozmowę z uczniem i „pochylenie się" nad nim. Problem jednak wynika raczej nie z tego, czy nauczyciele chcą wychowywać, ale z tego, czy potrafią to robić. Nie jest łatwo zapracować na miano autorytetu w oczach dzisiejszej młodzieży, taka właśnie rola autorytetu w działaniach wychowawczych jest ogromnie ważna. Nauczyciel nie może domagać się, aby uczniowie go szanowali, podziwiali, słuchali, naśladowali tylko dlatego, że pełni on wobec nich funkcję nadrzędną, jest ich przełożonym - nauczycielem. Musi on „całym sobą” zabiegać w kontaktach z wychowankami, aby dobrowolnie uznali oni, że warto mieć w jego postawie i przekonaniach punkt odniesienia. Uczniowie mający do czynienia $\mathrm{z}$ autorytetem będą pracować, angażując swoje siły w proces doskonalenia własnych umiejętności, aby jak najbardziej zbliżyć się do nauczyciela-mistrza. Czym wobec tego jest autorytet?

\footnotetext{
${ }^{8}$ B. Wlaźlik, B. Fischer, Kompetencje nauczyciela w zreformowanym systemie edukacji, [w:] R. Gmoch, A. Krasnodębska (red.), Kompetencje zawodowe nauczycieli..., s. 159.

${ }^{9}$ R. Kwaśnica (red.), Pytanie o nauczyciela, Wrocław 1993.
} 
Autorytet to pojęcie wieloznaczne. Mogą to być: konkretna osoba lub też jej określone cechy (umysłu, charakteru), które powodują, że jest ona ceniona przez innych. Autorytet (łac. auctoritas - powaga, znaczenie) to wpływ osoby lub organizacji cieszącej się ogólnym uznaniem w określonej sferze życia społecznego ${ }^{10}$. Józef Pieter w Słowniku psychologicznym definiuje autorytet jako

[...] przewagę czyją̧s nad pojedynczymi osobami lub grupami społecznymi (dzięki większej wiedzy, sile, lepszym cechom charakteru, władzy), wyrażającą się uznaniem i podporządkowaniem. Autorytet stanowi jeden z podstawowych czynników więzi społecznej w zorganizowanym życiu zbiorowym ${ }^{11}$.

Z kolei w socjologii występuje pojęcie „autorytaryzmu”, które definiuje się jako

[...] system wartości jednostek i grup, wynikający z całkowitego podporządkowania się intelektualnego i emocjonalnego jednostki lub grupy zewnętrznemu wobec niej autorytetowi indywidualnemu lub zbiorowemu ${ }^{12}$.

Pojęcie autorytetu było i jest także przedmiotem licznych dyskusji na gruncie pedagogiki. I tak np. Jan Władysław Dawid drogę do budowy autorytetu nauczyciela kojarzył z „miłością dusz ludzkich”13. Według Wincentego Okonia, autorytet ogniskuje w sobie to wszystko, co jest konsekwencją wykształcenia nauczyciela, jego osobistych walorów oraz jego działalności w szkole i w środowisku. Badacz ten zauważa też, że „osobista wartość człowieka nie wpływa w tym stopniu na owoce jego działalności, co w zawodzie nauczycielskim"14. Natomiast dla Stefana Szumana, nauczyciel z autorytetem to taki, który posiada talent pedagogiczny, czyli zdolności przerastające przeciętną normę i umożliwiające osiągnięcie nieprzeciętnych sprawności. Według Szumana, nie istnieje jedna cecha, która jest podłożem talentu, ale niewątpliwie podstawowy warunek talentu stanowi bogactwo osobowości. Utalentowany pedagog musi więc charakteryzować się dużą inteligencją, autentycznie kochać dzieci, znać swój przedmiot nauczania, posiadać dojrzałą osobowość oraz interesować się tym, czego naucza ${ }^{15}$. Z kolei Roman Ingarden autorytet nauczyciela kojarzył z etyką, moralnością. Zdaniem

\footnotetext{
${ }^{10}$ W. Okoń, Nowy słownik pedagogiczny, Warszawa 2004, s. 37.

${ }^{11}$ J. Pieter, Słownik psychologiczny, Katowice 2004, s. 45.

${ }^{12}$ J. Szczepański, Elementarne pojęcia socjologii, Warszawa 1970, s. 33.

${ }^{13}$ J. W. Dawid, O duszy nauczycielstwa, Warszawa 1959, s. 36.

${ }^{14}$ W. Okoń, O autorytecie nauczyciela, „Życie Szkoły” 1971, nr 1, s. 13.

${ }^{15}$ S. Szuman, Talent pedagogiczny, [w:] W. Okoń (oprac.), Osobowość nauczyciela, Warszawa 1959, s. 158.
} 
wspomnianego badacza, skuteczni są tylko ci nauczyciele i wychowawcy, którzy łączą swoje słowa z jednoznaczną postawą moralną ${ }^{16}$. We współczesnej pedagogice autorytet rozumiany jest jako szacunek, zaufanie, poważanie dla nauczyciela będącego ekspertem naukowym, doradcą, wzorem osobowym, a także osobą, z którą identyfikują się uczniowie ${ }^{17}$. Autorytet nauczyciela zależy od umiejętności przekształcania relacji z uczniem w kierunku autonomii i w atmosferze dialogu oraz wspólnego poszukiwania. Autorytet staje się zatem koniecznym warunkiem właściwego przebiegu procesu edukacji. Zdaniem Marii Dudzikowej, autorytet to bardzo rozległy i złożony temat. Wyróżnia się tutaj trzy opcje:

- liberalną,

- emancypacyjną,

- konserwatywną ${ }^{18}$.

W opcji liberalnej (reprezentowanej m.in. przez twórcę Szkoły Summerhill - Alexandra Sutherlanda Neilla), wyrastającej z idei „niewtrącania się" do rozwoju dziecka, postrzega się autorytet jako synonim autorytaryzmu. Z kolei w opcji konserwatywnej wyznacza się nauczycielowi rolę rzecznika - przekaźnika wartości niezmiennych, uniwersalnych. Nauczyciel zastępuje „niepewność” rodziny, szkoły. Stanowiskiem pośrednim jest opcja emancypacyjna. Nauczyciel pomaga uczniowi w osiągnięciu krytycznej wiedzy o podstawowych strukturach społecznych, aby instytucje te mogły być otwarte na potencjalną transformację. Zdaniem H. A. Giroux, nauczyciele nie mogą porzucać własnego autorytetu, ale powinni go przekształcać w emancypacyjną praktykę ${ }^{19}$. Autorytet staje się więc koniecznym warunkiem właściwego przebiegu edukacji. W literaturze przedmiotowej wyróżnia się następujące jego rodzaje:

- autorytet oparty na doświadczeniu życiowym wychowawcy, czyli na jego wiedzy, wykształceniu, zdolnościach i mądrości,

- autorytet desygnowany, odnoszący się do pozycji społecznej wychowawcy i wynikający z uznania dla jego stanowiska bądź funkcji (autorytet wewnętrzny);

\footnotetext{
${ }^{16}$ R. Ingarden, Książeczka o człowieku, Kraków 1987, s. 64.

${ }^{17}$ J. Lach-Rosocha, Kryzys wartości czy aksjologicznej świadomości współczesnego człowieka?, [w:] T. Lewowicki (red.), Pedagogika we wspótczesnym dyskursie humanistycznym, Kraków 2004, s. 297.

${ }^{18}$ M. Dudzikowa, Autorytet nauczyciela i edukacja. Trzy opcje, [w:] R. Kwiecińska, S. Kowala (red.), Edukacyjne drogi i bezdroża, Kraków 2002, s. 85-86.

${ }^{19}$ Ibidem, s. 98.
} 
- autorytet oparty na nieformalnych umowach, na zaufaniu, kontraktach, które wychowawcy zawierają w codziennych interakcjach ze swoimi wychowankami;

- autorytet wypływający z władzy, którą posiada osoba sprawująca zwierzchnictwo nad innymi ludźmi (autorytet zewnętrzny);

- autorytet emocjonalny, wynikający z szacunku, miłości lub też obawy, lęku wobec wychowawcy ${ }^{20}$.

Autorytet może oddziaływać na wychowanków wyzwalająco lub ujarzmiająco. Autorytet wyzwalający inspiruje i konstruktywnie wpływa na uczniów, aktywizując ich do samodzielnego działania, stymulując ich zapał, wyobraźnię, ale też pomagając im w osiąganiu cywilnej odwagi i krytycznej wiedzy. Współpraca $\mathrm{z}$ tak definiowanym autorytetem jest całkowicie dobrowolna. Natomiast autorytet ujarzmiający (stosowany w wychowaniu autorytarnym) pochodzi nie tyle z osobistych zalet, zasług, ile z wygórowanych ambicji i żądzy władzy nauczyciela. Dąży on do podporządkowania sobie uczniów poprzez stosowanie przymusu, ustanawianie arbitralnych zakazów lub nakazów.

Z pedagogicznego punktu widzenia najbardziej pożądany jest autorytet wyzwalający i wewnętrzny (autorytety prawdziwe). Część badaczy wyróżnia też autorytety pozytywne i negatywne ${ }^{21}$. Do pozytywnych zalicza się autorytet wiedzy, kultury i taktu, autorytet moralny. Natomiast wśród negatywnych znajduje się autorytet megalomanii (prezentowanie i utrwalanie negatywnego obrazu siebie w oczach dziecka), autorytet moralizatorstwa, przekupstwa, przemocy i autorytet dobroci (nadmiernej pobłażliwości dla dzieci). Józef Pieter, ujmując kompleksowo autorytet nauczyciela, stwierdza, że jest to „zespół różnorodnych właściwości, dzięki którym uczeń bez wyraźnych nakazów i bez strachu przed karą, ulega wychowawczemu wpływowi nauczyciela, a w szczególności chętnie uczy się stosować do jego wymagań" ${ }^{22}$. Z kolei aspekt szanowania osobowości ucznia, a także wskazywania mu drogi do pełnej wolności akcentował w swoich poglądach związanych $\mathrm{z}$ autorytetem nauczyciela Sergiusz Hessen ${ }^{23}$.

Analizując czynniki mające wpływ na autorytet nauczyciela, badacze wyróżnili dwa źródła: czynniki niezależne od nauczyciela i czynniki

\footnotetext{
${ }^{20}$ E. Badura, Emocjonalne uwarunkowania autorytetu nauczyciela, Warszawa 1980, s. 44.

${ }^{21}$ Ibidem.

${ }^{22}$ J. Pieter, Poznawanie środowiska wychowawczego, Wrocław-Kraków 1971, s. 56.

${ }^{23}$ S. Hessen, O sprzecznościach i jedności wychowania, Warszawa 1997, s. 49.
} 
zależne od nauczyciela ${ }^{24}$. Do pierwszej grupy zaliczono: pozycję szkoły $\mathrm{w}$ środowisku lokalnym, przedmiot nauczany przez nauczyciela, uznanie władz zwierzchnich (dyrekcji szkoły), atmosferę w gronie pedagogicznym. W drugiej grupie znalazły się: wiedza nauczyciela, metodyka (sposoby przekazywania wiedzy), cechy osobowościowe. $Z$ podziałem polemizuje wielu pedagogów. I tak np. zdaniem Lucyny Bojarskiej, od nauczycieli zależy: pozycja szkoły, atmosfera w gronie pedagogicznym, wiedza, metodyka, cechy osobowościowe. Natomiast czynnikami niezależnymi od nauczycieli, zdaniem wspomnianej autorki, są: uznanie władz zwierzchnich oraz uwarunkowania społeczno-polityczne ${ }^{25}$.

A jakie cechy uczniowie cenią u nauczycieli szczególnie?

Z badań Emilii Badury wynika, że uczniowie cenią sobie zwłaszcza nauczycieli, którzy znają, rozumieją i uwzględniają w pracy możliwości, predyspozycje uczniów, są serdeczni, życzliwi, spokojni i opanowani, a ponadto nie poniżają uczniów, odnoszą się do nich z szacunkiem, są empatyczni, liczą się z opinią swoich wychowanków ${ }^{26}$. Analizując powyższe cechy, należy jednak pamiętać, że oczekiwania uczniów względem nauczycieli są zmienną bardzo dynamiczną i w znacznej mierze zależą od wieku i etapu rozwojowego dzieci i młodzieży. I tak dla ucznia w klasach I-III szkoły podstawowej nauczyciel jest jedną z najważniejszych osób w życiu (zastępując dotychczasowy autorytet rodziców). Na tym etapie dzieci cenią sobie szczególnie takie cechy, jak serdeczność, życzliwość. W kolejnych klasach szkoły podstawowej (IV-VI) generalnie wzrasta krytycyzm uczniów w stosunku do osób dorosłych. Zaczynają oni dostrzegać przywary nauczycieli, ich ograniczone kompetencje. Chcą, aby nauczyciel traktował ich po partnersku, tym samym - szanował ich dojrzałość. Z kolei młodzież powyżej 13. roku życia, najwyżej ceni sobie wiedzę merytoryczną nauczyciela, jego umiejętności metodyczne. Ważna jest też jego etyka, uznanie dla niezależności młodych osób ${ }^{27}$.

Biorąc to pod uwagę, istotnym zagadnieniem wydaje się też określenie czynników obniżających autorytet nauczyciela we współczesnej szkole. Wśród nich należy wymienić m.in.:

\footnotetext{
${ }^{24}$ E. Badura, Emocjonalne uwarunkowania...

${ }^{25}$ L. Bojarska, Belfer na huśtawce. O autorytecie nauczyciela, Warszawa 2012.

${ }^{26}$ E. Badura, Emocjonalne uwarunkowania...

${ }^{27}$ L. Bojarska, Belfer na huśtawce...
} 
- wpływ mediów (które zainteresowane są wyłącznie nieprawidłowościami, sytuacjami skrajnymi w pracy nauczycieli; nie przedstawiają przykładów „dobrej” pracy nauczycieli),

- status finansowy nauczycieli (niestety we współczesnym społeczeństwie wysokość zarobków ma wpływ na postrzeganie człowieka),

- konflikty na terenie szkoły (zła atmosfera w gronie pedagogicznym),

- dyrekcja szkoły hamująca inicjatywy nauczycieli,

- utrata przez nauczycieli dominującej pozycji w przekazie wiedzy (Internet, telewizja).

Ponadto, co należy podkreślić, budowanie autorytetu nauczyciela szkolnych przedmiotów artystycznych jest szczególnie trudne, ponieważ przedmioty te od wielu już lat znajdują się na marginesie kształcenia ogólnego. Ich rola w procesie rozwoju dzieci i młodzieży jest często bagatelizowana. Tymczasem specyfika muzyki, plastyki, wiedzy o kulturze sprawia, że nauczyciel poprzez swoją wiedzę, umiejętności, zaangażowanie (fascynację zagadnieniami sztuki, kultury) może być dla wychowanków wzorem, autorytetem. Nauczyciel szkolnych przedmiotów artystycznych nie ogranicza się do przekazu uczniom wiedzy dotyczącej sztuki, kształtowania ich elementarnych umiejętności z tym związanych (ekspresyjnych i percepcyjnych). Będąc znawcą, pasjonatem, może, co ważne, ukształtować w młodzieży postawę twórczą, rozbudzić aktywność, nawyk działania, nie tylko w obszarze sztuki, ale i w innych sferach życia. Uczestnictwo uczniów w kulturze może być więc tutaj rozumiane jako przyswajanie treści kultury, podleganie im jako procesowi internalizacji i autokreacji, w wyniku którego wychowankowie gotowi będą do przekształcania siebie, świata, w zależności od przyjmowanych różnych wartości kultury. Przewodnikiem w tym procesie wychowania do sztuki i przez sztukę może być tylko dobrze przygotowany, świadomy swej roli i odpowiedzialności nauczyciel, a jednocześnie wychowawca - przyjaciel młodzieży.

W tym kontekście można zatem określić elementy, warunki, które sprzyjają budowaniu autorytetu nauczyciela. Będą to:

- podmiotowe traktowanie ucznia,

- wrażliwość pedagogiczna (związana z właściwą oceną sytuacji),

- takt pedagogiczny,

- zgodność własnego postępowania z głoszonymi ideami, poglądami,

- dbałość o informację zwrotną (dialog z uczniami), 
- równorzędne traktowanie wszystkich uczniów (sprawiedliwość, obiektywne kryteria oceny zgodne z akceptowanymi, jednolitymi normami).

Natomiast umocnieniu autorytetu nauczyciela mogą służyć:

- wysokie kwalifikacje moralne,

- życzliwość,

- doświadczenie (życiowe, zawodowe),

- równowaga emocjonalna.

Z pewnością współcześnie pojęcie autorytetu wymaga modyfikacji. Nauczyciel jest „człowiekiem spotkania i dialogu” z uczniem, ale jednocześnie jest zwierzchnikiem, egzekutorem poczynań wychowanków. Z jednej strony ma on wpływać na uczniów, kształtować ich, a z drugiej winien szanować ich autonomię, własne poglądy. Ma też rozbudzać ciekawość poznawczą uczniów, wątpliwości, a jednocześnie udzielać im konkretnych, rzetelnych odpowiedzi. Nauczyciel ma także wskazywać wychowankom najlepszą drogę do poruszania się w dorosłej rzeczywistości, ale również ma on kształtować postawy, zachowania twórcze, zwalczać konformizm. Przy tym wszystkim współczesny nauczyciel ma być przyjacielem, partnerem ucznia w dyskusji, zdobywaniu wiedzy, ale jednocześnie ma on zachować wymagany dystans i podział ról. Nauczyciel jako mistrz ma „wiedzieć i umieć więcej”, ale też musi pozwolić, by uczeń „przerósł” jego wiedzę i umiejętności. Nauczyciel zatem to z jednej strony profesja (wyuczona fachowość), ale z drugiej powołanie (którego nie można się „nauczyć”). Ideałem w kształtowaniu autorytetu byłoby więc zachowanie pomiędzy wymienionymi elementami równowagi ${ }^{28}$.

Wbrew panującym aktualnie poglądom o spadku znaczenia autorytetu $\mathrm{w}$ wychowaniu istnieje na niego duże zapotrzebowanie. Tę potrzebę wyznaczają racje znane od dawna w pedagogice, mówiące o tym, że wychowankowi, osobowości, która dopiero się kształtuje, niezbędnie potrzebny jest punkt odniesienia w postaci autorytetu. Nasilające się negatywne zjawiska życia społecznego sprawiają, że młodzi ludzie potrzebują aktualnie autorytetów, które pomogą im zrozumieć otaczającą rzeczywistość, odnaleźć w niej swoje miejsce, które udzielą im wsparcia w obszarze życia społecznego, przygotują do dokonywania racjonalnych wyborów.

${ }^{28}$ M. Leśniak, Autorytet nauczyciela - trudne wyzwanie wspótczesnej szkoły, „Nowa Szkoła” 2008, nr 10, s. 38-40. 


\section{Bibliografia}

Badura E., Emocjonalne uwarunkowania autorytetu nauczyciela, Warszawa 1980.

Bojarska L., Belfer na huśtawce. O autorytecie nauczyciela, Warszawa 2012.

Dawid J. W., O duszy nauczycielstwa, Warszawa 1959.

Gmoch R., Krasnodębska A. (red.), Kompetencje zawodowe nauczycieli i jakość kształcenia $w$ dobie przemian edukacyjnych, Opole 2005.

Hessen S., O sprzecznościach i jedności wychowania, Warszawa 1997.

Ingarden R., Książeczka o człowieku, Kraków 1987.

Kwaśnica R. (red.), Pytanie o nauczyciela, Wrocław 1993.

Kwiecińska R., Kowala S. (red.), Edukacyjne drogi i bezdroża, Kraków 2002.

Leśniak M., Autorytet nauczyciela - trudne wyzwanie współczesnej szkoły, „Nowa Szkoła” 2008, nr 10.

Lewowicki T. (red.), Pedagogika we współczesnym dyskursie humanistycznym, Kraków 2004.

Melighan R., Edukacja elastyczna. Jutro twojego dziecka decyduje się dzisiaj, Toruń 1991.

Okoń W., Nowy słownik pedagogiczny, Warszawa 2004.

Okoń W., O autorytecie nauczyciela, „Życie Szkoły” 1971, nr 1.

Okoń W. (oprac.), Osobowość, Warszawa 1959.

Prokopiuk W. (red.), Modernizacje systemów edukacyjnych a zawód nauczyciela, Białystok 1990.

Pieter J., Poznawanie środowiska wychowawczego, Wrocław-Kraków 1971.

Pieter J., Słownik psychologiczny, Katowice 2004.

Strykowski W., Kompetencje nauczyciela szkoły współczesnej, „Edukacja Medialna” 2002, nr 4.

Szczepański J., Elementarne pojęcia socjologii, Warszawa 1970.

Szymański, M., Nauczyciel jako profesjonalista, „Nowa Szkoła” 2005, nr 6. 